\title{
Influence of barometric pressure on odor discrimination and oviposition by adult plum curculios (Coleoptera: Curculionidae)
}

\author{
Tracy C. LESKEY* and RonALd J. PROKOPY \\ Department of Entomology, University of Massachusetts, Amherst, MA 01003, USA
}

Key words. Conotrachelus nenuphar, plum curculio, barometric pressure, oviposition, olfactory odor discrimination

\begin{abstract}
We conducted laboratory experiments to elucidate the influence of barometric pressure on odor discrimination and oviposition and feeding behavior of adult female plum curculios, Conotrachelus nenuphar (Herbst). Barometric pressure had a significant effect on Response Index values (used as a measure of odor discrimination); odor discrimination of hexane-extracted McIntosh fruit volatiles was high when barometric pressure was high. Barometric pressure also had a significant effect on oviposition as females oviposited more during periods of low barometric pressure on a favored host fruit (wild plum). Observed feeding activity of females was not influenced by barometric pressure.
\end{abstract}

\section{INTRODUCTION}

It is well documented that specific abiotic factors such as temperature, relative humidity, and day length exert a strong influence on insect behavior. In consequence, researchers conducting laboratory studies often aim to control abiotic as well as physiological factors to facilitate observation of a particular behavior under known conditions (Opp \& Prokopy, 1986). However, one abiotic factor that is generally not possible to control in a laboratory setting is barometric pressure, a factor that only a few studies of insect behavior have addressed.

An example of a laboratory study affected by barometric pressure is reported by Ankney (1984), who found that mating activity of Drosophila pseudoobscura Frolova was significantly diminished under reduced barometric pressure during passage of storm fronts. In our laboratory, we have conducted extensive studies of response to odors by adult plum curculios (Prokopy et al., 1995; Leskey \& Prokopy, 2000; Leskey et al., 2001), Conotrachelus nenuphar (Herbst) (Coleoptera: Curculionidae), a principal pest of stone and pome fruit (Racette et al., 1992). During these studies conducted in small still-air dual-choice olfactometers, we observed that plum curculio behavior changed markedly during the passage of storm fronts; adults quickly crawled to ceilings of olfactometers and often were observed trying to fly within them. These behaviors were not observed in the absence of storm fronts. We know from previous work that other abiotic factors, particularly temperature, are important in modulating plum curculio movement in the field (Prokopy et al., 1999). Furthermore, Dixon et al. (1999) found that barometric pressure was significantly and negatively correlated with fruit damage by plum curculios. Therefore, we initiated quantitative studies to determine the potential influence of barometric pressure

\footnotetext{
* Corresponding author. USDA, ARS, Appalachian Fruit Research Station, 45 Wiltshire Road, Kearneysville WV 25430, USA;

e-mail: tleskey@afrs.ars.usda.gov; phone: 304-735-3451 x329; fax: 304-728-2340.
}

on odor discrimination, as well as feeding and oviposition behavior of plum curculios in the laboratory.

\section{MATERIALS AND METHODS}

Plum curculios. All plum curculios used here were collected annually as overwintered adults in the field in late May or early June from populations present on unsprayed wild plum or apple trees in Hampshire County, MA in 1996-2000 and were assumed to be approximately the same age. Individuals were identified to sex within several hours of collection using criteria described by Thomson (1932) and were held in single sex groups of approximately 45 individuals in wax-coated paper cups $(473 \mathrm{ml})$ with clear plastic lids at $\sim 26^{\circ} \mathrm{C}, 65-80 \% \mathrm{RH}$ under a photoregime of $16 \mathrm{~L}: 8 \mathrm{D}$ to mimic long-day conditions in nature from late May to late June. Fresh food, either unsprayed wild plum or apple fruit, was provided along with a wetted cotton wick as a water source.

\section{Odor discrimination}

McIntosh fruit tissue extracts. In 1996-1998, fruiting tissue collections were made 1 week after bloom from unsprayed apple trees (cv. McIntosh) at the Horticultural Research Center of the University of Massachusetts in Belchertown on the following dates: 24 May (1996), 26 May (1997), and 12 May (1998). After collection, fruit tissues were taken to the laboratory for immediate processing. Extracts were made from fruiting tissues soaked in hexane or water as a solvent (in ratios of $1 \mathrm{ml}$ solvent per $2 \mathrm{~g}$ of tissue) for $24 \mathrm{~h}$ at room temperature. After 24 $\mathrm{h}$, tissues were pressed gently to remove any solvent that may have been absorbed and the extract was filtered through glass wool. Any solvent that had evaporated was added back during this step. All extracts were stored in a freezer at $-20^{\circ} \mathrm{C}$ until testing and were used in bioassays from mid May to late June of the year in which they had been prepared.

Bioassay procedure. A dual choice still-air system of enclosed Petri dishes, described by Prokopy et al. (1995), was employed to test attractiveness of volatiles from extracts. Test were conducted at $\sim 26^{\circ} \mathrm{C}, 65-80 \% \mathrm{RH}$ at the beginning of scotophase of a $16 \mathrm{~L}: 8 \mathrm{D}$ cycle, and were carried out from late May to late June in 1996, 1997, and 1998. A $75 \mu 1$ aliquot of fruit 
extract was pipetted onto a $1 \mathrm{~cm}$ square of cotton wick placed next to one of the two pipette tips that served as ports into the Petri dish chamber, and $75 \mu \mathrm{l}$ of corresponding solvent was pipetted onto a second cotton square placed next to the other pipette port. Extracts and controls were allowed to evaporate for approximately $4 \mathrm{~min}$ and then each port was covered with a transparent polystyrene cup. Female plum curculios collected from the field and held in the laboratory for less than two weeks were starved for $24 \mathrm{~h}$ and chilled for 15-20 min. in a cold room at $8-9^{\circ} \mathrm{C}$ just prior to testing. Handling was kept to a minimum A single female was placed gently in the center of each bioassay dish. Each replicate of a treatment consisted of 12 females tested singly in individual bioassay dishes held together on a tray. One replicate was evaluated per day. Dishes were moved immediately to the testing room. All bioassays lasted $2 \mathrm{~h}$. The number of replicates conducted in 1996, 1997 and 1998 was 22, 28 , and 18 , respectively, with only hexane extracts tested in 1996.

A positive response to either the treatment or control was considered to have occurred when a plum curculio crawled up the inner surface of one of the two tubes to enter a cup containing either the treatment or the control (Prokopy et al., 1995). Once a plum curculio crawled from a tube leading to a cup containing either the treatment or control, it nearly always remained under the cup and did not re-enter the tube. To measure the level of odor discrimination and attractiveness of volatiles, we used a Response Index (RI) developed by Phillips et al. (1993). The RI was calculated by subtracting the number of females responding to the control $(\mathrm{C})$ from the number responding to the treatment $(\mathrm{T})$, dividing the amount by the total number of females tested, and multiplying by 100 . Thus, $\mathrm{RI}=(\mathrm{T}-\mathrm{C} /$ total $) \times 100$; the greater the RI value, the greater the discrimination between the treatment and control and the more attractive the stimulus. Barometric pressure readings were taken at the beginning and end of each assay using a holosteric barometer (Forestry Supply, Inc. Jackson, MS), with daily averages of these readings converted to kilopascal $(\mathrm{kPa})$ units. The relationship between daily average $\mathrm{kPa}$ and daily RI values for 1996, 1997 and 1998 was analyzed using the SAS PROC GLM procedure (SAS Institute, 2001) to determine if odor discrimination by female plum curculios was significantly influenced by barometric pressure Overall average barometric pressure levels experienced by plum curculios during test periods were $100.363 \mathrm{kPa}+0.171 \mathrm{SE}$ $101.398 \mathrm{kPa}+0.089 \mathrm{SE}$, and $100.843 \mathrm{kPa}+0.166 \mathrm{SE}$ in 1996 , 1997 and 1998, respectively. Subsequent reference to low or high barometric pressure refers to barometric conditions above or below these average levels.

\section{Oviposition and feeding behavior}

Experimental procedure. All tests were conducted using field-collected individuals. Ten female plum curculios were held with 10 males and freshly picked wild plums for two days to ensure they were in a physiological state conducive to oviposition. On the third day, females were separated from males and plums for $24 \mathrm{~h}$. On the fourth day, a single female was held with either a clean, freshly picked unripe wild plum or approximately 5 blueberries (of similar volume to that of a wild plum), inside a wax-coated paper container and left for $4 \mathrm{~h}$. Wild plum was chosen to represent a highly favorable host for oviposition while blueberry represented a host of marginal value; these designations were based on number of adults reared from field samples of wild plum and blueberry fruit collected in Connecticut (Maier, 1990). Five randomly chosen females were tested daily with each fruit type in 1999. In 2000, 5-7 randomly chosen females were tested daily with plums only. After $4 \mathrm{~h}$, each female was removed and the number of feeding and oviposition sites present on each fruit was counted. Tests were conducted using different groups of females for each test day on 15 days during an 18-day period in 1999 (26 May to 11 June) and on 8 days during a 10-day period in 2000 ( 7 June to 16 June), the same period of time when oviposition and feeding activities were occurring in the field (Prokopy, unpublished data). We pooled results of all females tested during a given day; thus, 15 and 8 replicates were completed in 1999 and 2000, respectively. The relationship between daily average $\mathrm{kPa}$ and daily average number of eggs laid and daily average number of feeding punctures made on wild plums and blueberries was analyzed using the SAS PROC GLM procedure (SAS Institute, 2001) to determine if oviposition or feeding behavior by female plum curculios was significantly influenced by barometric pressure. Overall average barometric pressure levels experienced by plum curculios during test periods were $101.598 \mathrm{kPa}+0.145 \mathrm{SE}$ in 1999 and $101.072 \mathrm{kPA}+0.150 \mathrm{SE}$ in 2000 . Subsequent references to low or high barometric pressure refer to barometric conditions above or below these average levels.

\section{RESULTS}

Odor discrimination. The general linear model for RI values for hexane-based McIntosh fruit extracts was significant in $1996(\mathrm{~F}=5.81, \mathrm{df}=1,20, \mathrm{P}=0.03)$ and in $1998(\mathrm{~F}=4.22, \mathrm{df}=1,16, \mathrm{P}=0.05)$ as barometric pressure significantly influenced odor discrimination, but not in $1997(\mathrm{~F}=1.09, \mathrm{df}=1,25, \mathrm{P}=0.31)$. The general linear model for RI values for water-based McIntosh fruit extracts was not significant in $1997(\mathrm{~F}=0.87, \mathrm{df}=1,25$, $\mathrm{P}=0.36)$ or in $1998(\mathrm{~F}=0.05, \mathrm{df}=1,16, \mathrm{P}=0.83)$.

Oviposition behavior. The general linear model for oviposition scars on wild plums was significant at $\mathrm{P}=$ $0.07(\mathrm{~F}=3.78, \mathrm{df}=1,13)$ in 1999 and $\mathrm{P}=0.06(\mathrm{~F}=5.17$, $\mathrm{df}=1,6)$ in 2000 . This was not the case for blueberries in 1999 as the general linear model was not significant $(\mathrm{F}=$ $0.24, \mathrm{df}=1,13, \mathrm{P}=0.61$ ).

Feeding behavior. The general linear model for feeding scars was not significant for wild plums in 1999 ( $\mathrm{F}=0.01, \mathrm{df}=1,13, \mathrm{P}=0.93)$ and $2000(\mathrm{~F}=0.66, \mathrm{df}=1$, $6, \mathrm{P}=0.45)$ or for blueberries in $1999(\mathrm{~F}=1.14$, $\mathrm{df}=1$, $13, \mathrm{P}=0.31$ ).

\section{DISCUSSION}

Our results indicate that absolute level of barometric pressure influenced degree of female plum curculio odor discrimination in the laboratory. In both 1996 and 1998, there was a significant effect of barometric pressure on daily response indices for host McIntosh fruit volatiles extracted with hexane; lower RIs were recorded when barometric pressure was low. This was not the case in 1997. However, average barometric pressure level experienced by plum curculios was uniformly higher during test periods in $1997(101.398 \mathrm{kPa}+0.089 \mathrm{SE})$ than in 1996 $(100.363 \mathrm{kPa}+0.171 \mathrm{SE})$ or $1998(100.843 \mathrm{kPa}+0.166$ $\mathrm{SE})$, perhaps accounting for differences in results among years. Thus, we would predict a uniformly higher response index in 1997 compared to 1996 and 1998. Indeed, the overall average response index in 1997 (31.13 $\pm 3.28 \mathrm{SE})$ was much higher than in $1998(23.08 \pm 3.95$ $\mathrm{SE})$ but not in $1996(35.17 \pm 4.35 \mathrm{SE})$. However, changes 
in relative rather than absolute levels of barometric pressure may have influenced odor discrimination by females in our bioassays. For example, olfactory discrimination by Cotesia (= Apanteles) glomerata (L.), an endoparasitoid of Pieris sp., was greater during test periods of steadily increasing barometric pressure than during test periods of steadily decreasing or fluctuating barometric pressure (Steinberg et al., 1992). Furthermore, greater numbers of the parasitoid species Uscana lariophaga Steffan arrived at attractive odor sources in a simple diffusion olfactometer when absolute changes in barometric pressure were large (Ormel et al., 1995). We did not detect many changes in barometric pressure within the 2-hour time frame of our assays but this does not preclude the possibility that changes in barometric pressure over an unknown time frame prior to testing could have markedly influenced our results and account for differences observed between years. Perhaps using a computer controlled pressure device to observe plum curculio behavior such as the chamber designed by Goyette et al. (2002) could definitively answer this question. However, we also cannot discount the possibility of physiological variation among field-collected females of unknown age and mating status or variation among extracts prepared in 1996, 1997, and 1998 as reasons for differences in our results.

We observed diminished female odor discrimination of hexane-extracted host McIntosh fruit volatiles when barometric pressure was low, but did not observe this same trend with water-extracted McIntosh fruit volatiles. Volatile compounds comprising hexane- and water-extracted host fruit tested here were not identified, but compounds from aeration samples and hexane extracts of host fruit have been identified subsequently, and a number of apple-origin compounds were found to be attractive to adult plum curculios in the field (Prokopy et al., 2001). Perhaps there are other stimulating compounds present in our water-based extracts not present in our hexane-based extracts that can override effects of low barometric pressure, as evidenced by volatiles from host fruit extracted with water being more attractive to plum curculios than those extracted with hexane (Leskey \& Prokopy, 2000).

Barometric pressure also has been associated with changes in ovipositional activity of some insects. We observed increased oviposition by females in host plum fruit during periods of low barometric pressure in the laboratory, and Dixon et al. (1999) found that increased fruit injury by plum curculios was correlated with low barometric pressure in the field. Declining barometric pressure conditions were associated with increased oviposition in the parasitic wasp, Leptopilina heterotoma (Thompson); females wasps spent more time foraging for and ovipositing in both unparasitized and parasitized hosts under conditions of declining barometric pressure compared to steady barometric pressure (Roitberg et al., 1993). Roitberg et al. (1993) theorized that increased foraging and oviposition were a means to maximize lifetime fitness under conditions of decreased life expectancy. This result is in agreement with Wellington (1946), who demonstrated that storm fronts inflicted severe mortality on small, less robust insects. However, unlike L. heterotoma, which oviposited on a marginal host (a parasitized host), plum curculios did not oviposit on what could be considered a marginal host (blueberry), irrespective of barometric pressure. Perhaps because plum curculios are not soft-bodied insects, they are better able to survive inclement weather events and can be discriminating concerning ovipositional choices. However, female plum curculios do have a narrow time frame in which to locate host fruit trees and oviposit eggs in young fruit (Chapman, 1938). If females wait too long to deposit eggs, fruit will be too large and unsuitable for larval development. Thus, waiting for better weather to oviposit may not be a viable strategy. Perhaps female plum curculios increase ovipositional activity on suitable hosts when barometric pressure declines because fruit-foraging activities within host trees rarely involve flight (Prokopy $\&$ Leskey, unpublished data) and the sturdy nature of their coleopteran body affords them ample protection. Furthermore, foraging under such conditions could provide them with an opportunity to elude more fragile parasitoids and/or predators that may have difficulty foraging during stormy weather conditions.

In conclusion, we found that odor discrimination of adult female plum curculio in the laboratory was influenced by barometric pressure; female responses to hexane-based host fruit extracts declined during periods of low barometric pressure. Periods of low barometric pressure also increased oviposition on favored hosts but did not influence feeding behavior of females in our laboratory bioassays. We believe that laboratory and field studies of plum curculios and likely many other insect species should consider the potential influence of barometric pressure on observed behavioral patterns and their possible fitness consequences.

ACKNOWLEDGEMENTS. We thank Cathy Bramlage, Michele Bakis, Holly Gagne, Susan Nixson, Amy Weibe, Brian Hogg, Margaret Young, Anthea Yannopoulos, Monica Elmore, Beata Rzasa, Anthony Minalga, Amanda Ross, and E. Fidelma Boyd for their excellent technical assistance. Starker Wright and Juan Rull provided helpful comments to an earlier version of this manuscript. These studies were supported by USDA Hatch funding, the New England Tree Fruit Growers Association, and a University Fellowship to Tracy Leskey from the University of Massachusetts at Amherst.

\section{REFERENCES}

ANKNey P.F. 1984: A note on barometric pressure and behavior in Drosophila pseudoobscura. Behav. Gen. 14: 315-317.

Chapman P.J. 1938: The plum curculio as an apple pest. New York State Agricultural Experiment Station. Bulletin 684.

Dixon B.M., Prokopy R.J. \& Schultz B.B. 1999: Influence of weather and time of day on plum curculio (Coleoptera: Curculionidae) tree canopy entry behaviors and evaluation of traps for predicting fruit injury. J. Entomol. Sci. 43: 191-202.

Goyette B., Vigneault C., Fourniter F. \& Borvin G. 2002. Design of a computer controlled pressure chamber for insect behavioral studies. Computer. Electr. Agr. 33: 85-90.

Leskey T.C., Prokopy R.J., Wright S.E., Phelan P.L. \& Haynes L.W. 2001: Evaluation of individual components of plum 
odor as potential attractants for adult plum curculios. $J$. Chem. Ecol. 27: 1-17.

Leskey T.C. \& Prokopy R.J. 2000: Sources of apple odor attractive to plum curculios. J. Chem. Ecol. 26: 639-653

MAIER C.T. 1990: Native and exotic rosaceous hosts of apple, plum and quince curculio larvae (Coleoptera: Curculionidae) in the northeastern United States. Environ. Entomol. 83: $1326-1332$.

OpP S.B. \& Prokopy R.J. 1986: Approaches and methods for direct behavioral observation and analysis of plant-insect interactions. In: Miller J.R. \& Miller T.A. (eds): Insect-Plant Interactions. Springer-Verlag, New York, pp. 1-22.

Ormel G.J., Gort G. \& Alebeek van F.A.N. 1995: Analyzing host location in Uscana lariophaga (Hymenoptera: Trichogrammatidae), an egg parasitoid of bruchids (Coleoptera: Bruchidae) using Cox's proportional hazards model. Bull. Entomol. Res. 85: 113-123.

Phillips T.W., Jiang X. L., Burkholder W.E., Phillips J. K. \& TRAN H.Q. 1993: Behavioral responses to food volatiles by two species of stored-product Coleoptera, Sitophilus oryzae and Tribolium castaneum. J. Chem. Ecol. 19: 723-734.

Prokopy R.J., Phelan P.L., Wright S.E., Minalga A.J., Barger R. \& LESKEY T.C. 2001: Compounds from host odor attractive to plum curculio adults (Coleoptera: Curculionidae). J. Entomol. Sci. 36: 122-134.
Prokopy R.J., Wirth C.B. \& Leskey T.C. 1999. Movement of plum curculios toward host trees and traps: flight versus walking. Entomol. Exp. Appl. 91: 385-392.

Prokopy R.J., Cooley S.S. \& Phelan P.L. 1995: Bioassay approaches to assessing behavioral responses of plum curculio adults (Coleoptera: Curculionidae) to host fruit odor. $J$. Chem. Ecol. 21: 1073-1084.

RoItberg B.D., Sircom J., Rottberg C.A., Alphen Van J.J.M. \& Mangel M. 1993: Life expectancy and reproduction. Nature 364: 108.

Racette G., Chouinard C., Vincent C. \& Hill S.B. 1992: Ecology and management of the plum curculio, Conotrachelus nenuphar, (Coleoptera: Curculionidae) in apple orchards. Phytoprotection 73: 85-99.

SAS InSTITUTE 2001: Version 8.2, SAS Institute Inc., Cary, NC.

Steinberg S., Dicke M., Vet L.E.M. \& Wannigen R. 1992: Response of the braconid parasitoid Cotesia (=Apanteles) glomerata to volatile infochemicals: effects of bioassay set-up, parasitoid age and experience and barometric flux. Entomol. Exp. Appl. 63: 163-175.

Thomson R.R. 1932: Sex differentiation of adults of Conotrachelus nenuphar. J. Econ. Entomol. 25: 807-810.

WELLINGTON W.G. 1946: The effects of variations in atmospheric pressure upon insects. Can. J. Res. Sect. D. 24: 51-70.

Received August 19, 2002; revised October 13, 2002; accepted March 3, 2003 